S. Afr. J. Agric. Ext.

Maoba

Vol. 44, No. 2, 2016: $167-173$

DOI: http://dx.doi.org/10.17159/2413-3221/2016/v44n2a415

(Copyright)

\title{
FARMERS' PERCEPTION OF AGRICULTURAL EXTENSION SERVICE DELIVERY IN GERMISTON REGION, GAUTENG PROVINCE, SOUTH AFRICA
}

Maoba, S. $^{36}$

\begin{abstract}
This study was conducted to determine farmers' perception of extension service delivery in Germiston Region, Gauteng Province, South Africa. Both purposive and simple random sampling techniques were used for the sample selection and questionnaire was used to elicit information from 78 respondents. Data were analysed using descriptive statistics such as mean, frequency counts, percentages and standard deviation. Results showed that farmers perceived training $(M=3.6, S D= \pm 0.5)$ and demonstrations $(M=3.6, S D= \pm 0.48)$ to be highly effective in the study area. Results also indicated that $42.31 \%$ of farmers were visited once a month by agricultural advisors. The study further revealed that extension activities had low impact on improving farm production yield and profitability $(M=1.9, S D= \pm 0.67)$ and enabling farmers to identify their own needs, problems and solve them $(M=1.9, S D= \pm 0.69)$. In conclusion it was found that extension is efficient, effective and visible in the study area. The study recommended a review on extension methods perceived to be non-effective or slightly effective and collaboration between stakeholders for a strong extension services. It will be imperative to ensure that methods regarded to be effective are mainly used to deliver extension messages.
\end{abstract}

Keywords: Extension Service Delivery, Farmers' Perception, Effectiveness.

\section{INTRODUCTION}

Agriculture is the mainstay of most African countries and occupies a pivotal role in the development of the continent. It also remains an important sector in the South African economy due to its central role in building a strong economy, reducing inequalities by increasing incomes and employment opportunities for the poor, while nurturing natural resources (Oladele, 2015:30).

Dissemination of the right information at the appropriate time among farmers is key to providing change in agriculture (Asiedu-Darko, 2013:37). The agricultural sector is crucial to rural development and contributes significantly to any initiative to alleviate poverty. For this reason there is a great need for effective extension and advisory services. Agricultural extension in South Africa has undergone fundamental change from a dualistic service (separate services for commercial and small-scale farmers) to a single amalgamated service, focusing on the needs of both the previously disadvantaged small-scale farmers and the largescale commercial farmers (DOA, 2005:1). In Gauteng Province extension service is still largely the responsibility of the Gauteng Department of Agriculture and Rural Development (GDARD).

The South African agricultural extension service is challenged to improve food security, develop the rural areas through agricultural activity and to create sustainable jobs in

\footnotetext{
${ }^{36}$ Assistant Director: Extension and Advisory Services, Gauteng Department of Agriculture and Rural development. $3^{\text {rd }}$ Floor ABSA Building, cnr Odendaal Street and Victoria St, Germiston. Email:

Seabata.Maoba@gauteng.gov.za.
} 
S. Afr. J. Agric. Ext.

Maoba

Vol. 44, No. 2, 2016: $167-173$

DOI: http://dx.doi.org/10.17159/2413-3221/2016/v44n2a415

(Copyright)

agriculture. This is essentially promoted through the transfer of information and technologies to farmers in order to increase sustainable agriculture (Van Niekerk, Stroebel, Van Rooyen, Whitfield \& Swanepoel, 2011:57). The crucial role of agricultural extension in the social and economic development of the nation cannot be over-emphasized (Anaeto, Asiabaka, Nnadi, Ajaero, Aja, Ugwoke, Ukpongson \& Onweagba, 2012:180).

Agricultural extension service is one of the main instruments used by Provincial Department of Agriculture to achieve its agricultural developmental goals. The goals could be achieved through provision of appropriate agricultural information and knowledge to enable and capacitate land users and farmers towards improved, sustainable and economic development (Zwane, Groenewald \& Van Niekerk, 2014:49). This explains why agricultural extension remains one of the strategies for rural development throughout the world, assist farmers to determine their own problems, help them find desirable solutions and encourage them to take action (Anaeto et al., 2012:182).

Extension services can be organized and delivered in a variety of forms, but their ultimate aim is to increase farmers' productivity and income (Kassem, 2014:93). However, farmers are often blamed for poor adoption of extension services and success or failure is based on the level of adoption without considering the effectiveness of extension delivery mechanisms. According to Ajala, Ogunjimi, \& Farinde (2013:72) there are numerous problems facing the agricultural extension service such as high level of illiteracy among farmers which sometimes make it difficult for them to comprehend all the ideas being communicated to them. Even after communicating the ideas, some of the farmers cannot subsequently translate the ideas to practice. In the same vein, most of the farmers are conservative and are not ready to accept any positive changes. In Gauteng Province agricultural extension officials have being criticized by some famers for not being visible, effective and efficient when doing their job. It is against this background that this study was carried out to determine farmers' perception on agricultural extension services delivery in Germiston, Gauteng Province, South Africa.

\section{OBJECTIVE OF THE STUDY}

The main objective of the study was to determine farmers' perception of agricultural extension service delivery in Germiston Region of Gauteng Province, South Africa. The specific objectives were to:

2.1 Determine farmers' perception of effectiveness of extension methods.

2.2 Determine farmers' perception of impact of extension activities on their livelihood.

\section{METHODOLOGY}

The study was conducted in Germiston Region, Gauteng Province, South Africa. Germiston Region is constituted by the Ekurhuleni Metropolitan Municipality and Sedibeng District Municipality.

Both purposive and simple random sampling methods were used to interview only smallholder farmers who participate in agricultural extension activities in Germiston region, Gauteng Province. A questionnaire was designed to elicit information on farmers' perception of extension service delivery. This questionnaire was administered to 78 smallholder farmers (respondents) during focus group sessions to obtain primary data for the study. 
A 4 and 3 point Likert-type scale method and mean score were used to determine farmers' perception of effectiveness of extension methods and impact of extension activities on their livelihood, respectively. For a given extension method the mean was computed by taking the sum of the products between the number of responses and grade point and then divided by the total number of responses. Extension methods with mean value less than 2.5 were regarded to be either slightly or not effective while those with mean value equal to or more than 2.5 were considered to be effective or very effective. In order to determine the impact of extension activities the mean value less than 2 were regarded to be having no impact while those with mean value equal or more than 2 were considered to be having an impact. Data were sorted, coded then analysed using descriptive statistics such as of means, frequency counts, percentages and standard deviation.

\section{RESULTS AND DISCUSSIONS}

\subsection{Perception of respondents on effectiveness of extension methods}

The findings on farmers' perception on effectiveness of extension methods are as shown in Table 1. The results revealed that out of ten (10) extension methods, only two (2) methods were perceived to be highly effective by farmers in the study area which were training and demonstrations with a mean value of $3.6(\mathrm{SD}= \pm 0.50$ and $\mathrm{SD}= \pm 0.48)$. While, study groups $(\mathrm{M}=3.1, \mathrm{SD}= \pm 0.79)$, farmers days $(\mathrm{M}=3.0, \mathrm{SD}= \pm 1.12)$, individual farm visits $(\mathrm{M}=2.8$, $\mathrm{SD}= \pm 0.92)$ and on-farm trials and research $(\mathrm{M}=2.5, \mathrm{SD}= \pm 0.98)$ were perceived to be effective. The study further revealed that the following extension methods were perceived to be slightly effective by farmers, workshops $(\mathrm{M}=2.1, \mathrm{SD}= \pm 1.05)$, print materials $(\mathrm{M}=2.1$, $\mathrm{SD}= \pm 1.02)$ and office calls $(\mathrm{M}=1.9, \mathrm{SD}= \pm 0.98)$. While, telephone calls $(\mathrm{M}=1.5, \mathrm{SD}=0.73)$ perceived to be not effective by famers in the study area. The implications of the findings are that most of extension methods used by agricultural advisors in Germiston region are effective. It will be imperative to ensure that methods regarded to be effective are mainly used to deliver extension messages. Officials should be encouraged to do away or minimise the application of extension methods perceived to be slightly or not effective. Continuation with such methods may results in non-participation of farmers to extension activities since it has been considered to be non-effective. According to Aphunu \& Otoikhian (2008:167) there is the need for regular training for extension agents so that reasonable knowledge and experience in adult learning principles could be acquired to enhance their effectiveness. 
Table 1: Perception of respondents on effectiveness of extension methods $(\mathrm{N}=78)$

\begin{tabular}{|l|l|l|l|l|l|l|l|}
\hline Methods & $\begin{array}{l}1: \text { Not } \\
\text { effective }\end{array}$ & $\begin{array}{l}2: \text { Slightly } \\
\text { effective }\end{array}$ & $3:$ Effective & $\begin{array}{l}4: \text { Highly } \\
\text { effective }\end{array}$ & Mean & SD & Ranking \\
\hline Training & - & - & $34[43.59]$ & $44[56.41]$ & $3.6^{* * *}$ & 0.50 & $1^{\text {st }}$ \\
\hline Demonstrations & - & - & $28[35.90]$ & $50[64.10]$ & $3.6^{* * *}$ & 0.48 & $1^{\text {st }}$ \\
\hline Study groups & - & $20[25.64]$ & $28[35.90]$ & $30[38.46]$ & $3.1^{* *}$ & 0.79 & $3^{\text {rd }}$ \\
\hline Farmers days & $12[15.38]$ & $11[14.10]$ & $18[23.08]$ & $37[47.44]$ & $3.0^{* *}$ & 1.12 & $4^{\text {th }}$ \\
\hline $\begin{array}{l}\text { Individual Farm } \\
\text { visit }\end{array}$ & $9[11.54]$ & $14[17.95]$ & $37[47.43]$ & $18[23.08]$ & $2.8^{* *}$ & 0.92 & $5^{\text {th }}$ \\
\hline $\begin{array}{l}\text { On-farm trails } \\
\text { and research }\end{array}$ & $14[17.95]$ & $21[26.92]$ & $30[38.46]$ & $13[16.67]$ & $2.5^{* *}$ & 0.98 & $6^{\text {th }}$ \\
\hline Workshops & $30[38.46]$ & $23[29.49]$ & $15[19.23]$ & $10[12.82]$ & $2.1^{*}$ & 1.05 & $7^{\text {th }}$ \\
\hline Print Materials & $27[34.62]$ & $30[38.46]$ & $10[12.82]$ & $11[14.10]$ & $2.1^{*}$ & 1.02 & $7^{\text {th }}$ \\
\hline Office calls & $37[47.43]$ & $20[25.64]$ & $15[19.23]$ & $6[7.70]$ & $1.9^{*}$ & 0.98 & $9^{\text {th }}$ \\
\hline Telephone calls & $53[67.95]$ & $14[17.95]$ & $11[14.10]$ & - & $1.5^{*}$ & 0.73 & $10^{\text {th }}$ \\
\hline
\end{tabular}

Source: Field Survey 2016, *Slightly effective; **Effective, ***Highly effective

\subsection{Frequency of farm visit by agricultural advisors}

Results in Table 2, indicates that only $24.36 \%$ of farmers are visited very often (fortnightly), $42.31 \%$ are visited once a month and $33.33 \%$ of farmers in the study area are visited occasionally. However, irregular farm visits can lead to farmers complain about invisibility of agricultural advisors and that could impact negatively on extension activities. It is important for agricultural advisors to visit farmers often. Provision of transportation as a working tool is crucial in order for that to be realised. However, visits should be meaningful and have a purpose in order to have a positive impact to the farming community. Although, the study is in agreement with the findings of Aphunu \& Otoikhian (2008:167) that majority of the farmers have contact with extension agents on a monthly basis. However, more attention is needed to reduce the current percentages of $33.33 \%$ of irregular visit, since that would translate to high percentages of farmers reached on a monthly basis.

Table 2: Frequency of farm visit $(\mathrm{N}=78)$

\begin{tabular}{|l|l|l|}
\hline VISIT & Frequency & Percentage \\
\hline Very often (fortnightly) & 19 & 24.36 \\
\hline Often (once a month) & 33 & 42.31 \\
\hline Occasionally (irregular) & 26 & 33.33 \\
\hline
\end{tabular}

Source: Field Survey 2016

\subsection{Impact of extension service delivery}


Vol. 44, No. 2, 2016: $167-173$

DOI: http://dx.doi.org/10.17159/2413-3221/2016/v44n2a415

(Copyright)

The results on farmers' perception of impact of extension activities are as shown in Table 3. The study revealed that extension activities had low impact on improving farm production yield or output and profitability $(\mathrm{M}=1.9, \mathrm{SD}= \pm 0.67)$ and also on enabling farmers to identify their own needs, problems and solve them $(\mathrm{M}=1.9, \mathrm{SD}= \pm 0.69)$. This could be attributed to a top down approach. It is critical that agricultural advisors work together with farmers in planning production activities and other farm management aspects. The approach will equip farmers to be able to identify and address challenges they may encounter in farming endeavors. Sinkaiye (2005) reported that the role of agricultural extension involves building capacity of farmers and help them make informed decisions. However, the effectiveness of extension service is highly dependent on the ability of competent extension workers to transfer information to the farmer (AL-Sharafat, Altarawneh \& Altahat, 2012:195). Furthermore, the study found that extension activities have high impact on management practices $(\mathrm{M}=2.5, \mathrm{SD}= \pm 0.64)$, rate of adoption of new technology $(\mathrm{M}=2.3, \mathrm{SD}= \pm 0.60)$ and level of understanding on marketing issues $(\mathrm{M}=2.0, \mathrm{SD}= \pm 0.72)$. These findings confirm the effectiveness of extension methods, commitments of farmers in the study area and dismiss the notion that agricultural extension in Germiston region is not effective. However, it is imperative to note that a lot of work is still needed to be done to improve the level of impact on some indicators. Strong or effective agricultural extension can contributes significantly towards an improved or high yield and that can leads to sustainable agriculture which will attributes to food security, poverty alleviation and job creation. While weak agricultural extension can result in low or poor yield, leading to vulnerability, that can cause economic depression i.e. food insecurity, job losses and poverty (Figure1). According to Sallam (1994) the role of extension is very important to support sustainable agriculture which is moving from production to a wider set of sustainability. Hence it's imperative to have strong agricultural extension service delivery. That would lead towards increase participation of farmers and restore confidences in extension activities. Since, the success of an extension programme largely depends on the roles played by farmers in the programme (Wasihun, Kwarteng \& Okorley, 2014:80).

Table 3: Perception of respondents on impact of extension service delivery ( $\mathrm{N}=78)$

\begin{tabular}{|l|l|l|l|l|l|l|}
\hline IMPACT & $\begin{array}{l}\text { 1:No } \\
\text { impact }\end{array}$ & $\begin{array}{l}\mathbf{2 : L o w} \\
\text { impact }\end{array}$ & $\begin{array}{l}\text { 3:high } \\
\text { impact }\end{array}$ & Mean & SD & Ranking \\
\hline $\begin{array}{l}\text { Improved your farm } \\
\text { production yield and } \\
\text { profitability }\end{array}$ & $21[26.92]$ & $\begin{array}{l}43[55.1 \\
3]\end{array}$ & $14[17.95]$ & $1.9^{*}$ & 0.67 & $4^{\text {th }}$ \\
\hline $\begin{array}{l}\text { Your management } \\
\text { practices has improved }\end{array}$ & $6[7.69]$ & $\begin{array}{l}24[30.7 \\
7]\end{array}$ & $48[61.54]$ & $2.5^{* *}$ & 0.64 & $1^{\text {st }}$ \\
\hline $\begin{array}{l}\text { Your rate of adoption of } \\
\text { new technology has } \\
\text { increased }\end{array}$ & $5[6.41]$ & $\begin{array}{l}40[51.2 \\
8]\end{array}$ & $33[42.31]$ & $2.3^{* *}$ & 0.60 & $2^{\text {nd }}$ \\
\hline $\begin{array}{l}\text { Able to identify your own } \\
\text { needs, problems and solve } \\
\text { them }\end{array}$ & $20[25.64]$ & $\begin{array}{l}41[52.5 \\
6]\end{array}$ & $17[21.80]$ & $1.9^{*}$ & 0.69 & $4^{\text {th }}$ \\
\hline $\begin{array}{l}\text { Effectively understand } \\
\text { marketing issues }\end{array}$ & $18[23.08]$ & $\begin{array}{l}38[48.7 \\
2]\end{array}$ & $22[28.20]$ & $2.0^{* *}$ & 0.72 & $3^{\text {rd }}$ \\
\hline
\end{tabular}

Source: Field Survey 2016, *Low impact, **High impact 


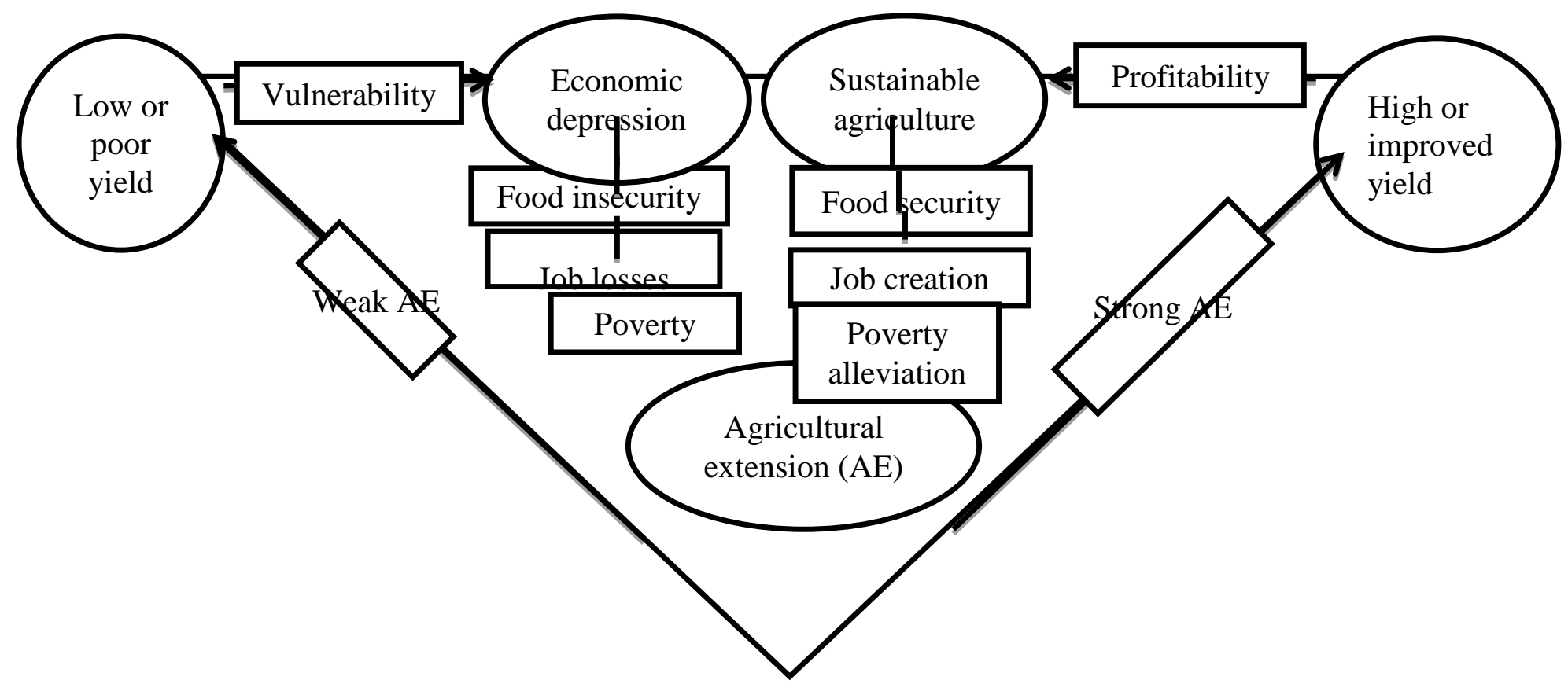

Figue1: Agricultural extension impact pathway (developed by the author)

\section{CONCLUSION AND RECOMMENDATIONS}

The results of the study indicated that applications of some of the extension methods are perceived to be effective by farmers in the study area and have impact. Regular farm visit is crucial for dissemination of extension massages and should be encouraged. However, visits should be meaningful and have a purpose in order to have a positive impact. In order, for agricultural extension to impact on the livelihood of farmers and farming community at large, there is a need for a strong agricultural extension and that can be achieved if all stakeholders work and plan together. The study dismisses the notion that extension in Germiston Region is inefficient, ineffective and invisible. Although, a review on extension methods perceived to be non-effective or slightly effective is needed, that could be attributing to the sentiments of the farmers that extension is weak. It will be imperative to ensure that methods regarded to be effective are mainly used to deliver extension messages.

\section{REFERENCES}

AJALA, A. O., OGUNJIMI, S. I. \& FARINDE, A. J. 2013. Assessment of extension service delivery on improved Cassava technologies among Cassava farmers in Osun State, Nigeria. Int. J. Appl. Agr. and Apicult. Res. 9 (1\&2): 71-80.

AL-SHARAFAT, A., ALTARAWNEH, M. \& ALTAHAT, E. 2012. Effectiveness of agricultural extension activities. Am. J. Agri. \& Biol. Sci., 7 (2): 194-200.

ANAETO, F. C., ASIABAKA, C. C., NNADI,F.N., AJAERO, J. O., AJA, O. O., UGWOKE, F. O., UKPONGSON, M. U. \& ONWEAGBA, A. E. 2012. The role of extension officers and extension services in the development of agriculture in Nigeria. J. Agric. Res. 1(6):180-185 
Vol. 44, No. 2, 2016: $167-173$

DOI: http://dx.doi.org/10.17159/2413-3221/2016/v44n2a415

APHUNU, A. \& OTOIKHIAN, C. S. O. 2008. Farmers' perception of the effectiveness of extension agents of Delta State Agricultural Development Programme (DADP). Afr. J. Gen. Agric. 4(3):165-169.

ASIEDU-DARKO, E. 2013. Agricultural extension delivery in Ghana: A case study of factors affecting it in Ashanti, Eastern and Northern regions of Ghana. J. Agr. Ext. and Rural Dev. 5(2): $37-41$.

DEPARTMENT OF AGRICULTURE (DOA). 2005. Norms and standards for extension and advisory services in Agriculture. www.nda.agric.za

KASSEM, H. S. 2014. Effectiveness of different agricultural extension methods in providing knowledge and skills in disease prevention: A case of Smallholder Poultry Production Systems in Dakhalia Governorate of Egypt. Asian J. Agr. Ext. Eco \& Sociol. 3(2): 91107.

OLADELE, O. I. 2015. Effect of information communication technology (ICT) on agricultural information access among extension officers in North West Province South Africa. S. Afr. J. Agric. Ext. 43(2): 30-41.

SALLAM, M. S. 1994. Expectations from farmers in mediterranean southern countries: The case of Egypt. J. Cahiers Options Mediterranean's, 2: 119-122.

SINKAIYE, T. 2005. 'Agricultural extension participatory methodologies and approaches', in S.F. Afolayan (ed.), Agricultural Extension in Nigeria, AESON, Ilorin, pp. 220-233.

WASIHUN, B. N., KWARTENG, J. A. \& OKORLEY, E. L. 2014. Farmer's perception of their level of participation in extension in Ethiopia: Policy implications. J. Agric. Ext. and Rur. Dev. 6(2):80-86.

VAN NIEKERK, J. A., STROEBEL, A., VAN ROOYEN, C. J., WHITFIELD, K. P., SWANEPOEL, F. C. J. 2011. Towards redesigning the Agricultural extension service in South Africa: views and proposals of extensionists in the Eastern Cape. S Afr. J. Agric. Ext. 39 (2):57-68.

ZWANE, E. M., GROENEWALD, I. B \& VAN NIEKERK, J. A. 2014. Critical factors influencing performance of extensionists in Limpopo Department of Agriculture in South Africa. S. Afr. J. Agric. Ext. 42:49-61. 